\title{
Pre and post-operative oxidative stress level in cases with ovarian neoplasia
}

\author{
Mustafa Bilici ${ }^{1}$, Numan $\mathrm{Cim}^{2}$, Halit Demir ${ }^{1}$
}

\begin{abstract}
Objective: The aim of this study is to analyze the serum antioxidant enzyme activities and oxidative stress levels in patients with ovarian neoplasia. Oxidative stress is considered to play a role in the pathogenesis of many diseases such as cancer, diabetes and heart condition. Antioxidants are involved in the removal of carcinogen lipid soluble radicals produced by lipid peroxidation.

Material and Methods: This study, pre and post-operative serum glutathione (GSH), superoxide dismutase (SOD), serum catalase (CAT) activity, and malondialdehyde (MDA) levels were investigated in the patient with ovarian neoplasia.

Results: The reduced serum glutathione (GSH) activity was observed to decrease in patients with ovarian cancer $(p<0.05)$. Serum superoxide dismutase (SOD) activities were found to be lower in patients with ovarian cancer compared to the healthy control group $(\mathrm{p}<0.05)$. Meaningfully high serum malondialdehyde (MDA) levels were found in patients with ovarian cancer $(\mathrm{p}<0.05)$. The serum catalase (CAT) activity was found significantly lower in patients with ovarian cancer than controls $(p<0.05)$.

Conclusion: In this study, oxidative stress levels have been increased and also antioxidant enzyme activities have been decreased in patients with ovarian cancer. Decreased serum antioxidant enzyme activities can play a role in the development of cancer. This study aims to light the way for other studies.
\end{abstract}

Keywords: Ovarian Neoplasia, Reduced Glutathione, Catalase, Malondialdehyde, Superoxide Dismutase Activity

Introduction

Oxidative stress can be underlying reason for many neurodegenerative diseases, such as Alzheimer's, Parkinson's, amyotrophic lateral sclerosis, inflammatory diseases, rheumatoid arthritis, cardiovascular disease, and muscular dystrophy, etc. It is also causes allergies, immune system disorders, diabetes, aging and various types of cancer. For example, inflammatory cells release chemical mediators of inflammation, particularly ROS, in tissue; when this occurs, the extremely high ROS levels cause cell damage and block the cell defense mechanisms (e.g. antioxidants) and inhibit detoxification [1].

Due to importance of oxidative balance, this study aims to reveal the relation between the serum MDA, GSH, SOD and CAT activities and neoplasia in patients with ovarian neoplasia.

\section{Materials and Methods}

The case group of this study was consisted of 35 ovarian cancer diagnosed patients, who were admitted to the gynecology wards of Dursun
Odabasi Medical Center in the University of YuzuncuYil and Van Regional Education and Research Hospital between May 2013 and February 2014. A control group consisting of 35 healthy woman volunteers was included in the study. The study was commenced after obtaining the approval of the local ethics committee. Written informed consent was obtained from the patients for conducting the study.

Sample analysis: Brachial vein blood samples (3 $\mathrm{ml}$ ) were taken from the cases in the patient group (both before the operation and 1 month after the operation) and the control group. Blood samples taken into venous biochemistry tubes were separated by centrifugation in Nuve NF 800 centrifuge at $5000 \mathrm{rpm}$ for 15 minutes, and obtained serums were preserved at $-80{ }^{\circ} \mathrm{C}$ until they were processed. When the adequate numbers of samples were obtained, serum malondialdehyde (MDA) levels and superoxide dismutase (SOD), reduced glutathione (GSH) and catalase (CAT) activities were spectrophotometrically measured in the

Received: 15Oct. 2014, Revised 17Oct. 2014, Accepted 22Oct. 2014, Available Online 25Oct. 2014

${ }^{1}$ Yuzuncu YilUniversity, Faculty of Science, Division of Biochemistry, Department of Chemistry, 65080, Van, Turkey.

${ }^{2}$ Yuzuncu Yil University, Faculty of Medicine, Department of Obstetrics and Gynecology, 65080 Van, Turkey.

*Corresponding Author: Mustafa BiliciE-mail:mbilici65@hotmail.com.tr 
Biochemistry laboratories of the Department of Chemistry, Faculty of Science, University of YuzuncuYil.

Determination of MDA Levels: $0.8 \mathrm{ml}$ of phosphate buffer, $0.025 \mathrm{ml}$ of BHT and $0.5 \mathrm{ml}$ of $30 \%$ TCA were added on $0.2 \mathrm{ml}$ of serum. The tubes were vortex mixed and incubated in ice for 2 hours. They were then centrifuged at $2.000 \mathrm{rpm}$ for 15 minutes. $1 \mathrm{ml}$ of supernatant was taken into another tube. Then, $0.075 \mathrm{ml}$ of $0.1 \mathrm{M}$ EDTA and $0.025 \mathrm{ml}$ of $1 \%$ TBA were added. The tubes are mixed and incubated in boiling water bath for 15 minutes. After being cooled down to the room temperature, absorbance was spectrophotometrically measured at $532 \mathrm{~nm}$ in Hitachi U-2900 originated from Tokyo-Japan [2].

Determination of SOD Activities: The enzyme was spectrophotometrically measured (AtiUnicam UV/VIS-UV2-100, England) using commercial kits of the brand Randox (Randox: 55 Diamond Road, Crumlin, Co. Antrim, United Kingdom, BT29 4QY) and absorbance values were read in Hitachi U-2900 [3].

Determination of GSH Activities: $0.8 \mathrm{ml}$ of phosphate buffer was added in each tube containing $0.2 \mathrm{ml}$ of serum and the GSH activities were measured at $412 \mathrm{~nm}$. Then, $0.1 \mathrm{ml}$ of DTNB was added and optical density was read at $412 \mathrm{~nm}$ in Hitachi U-2900 [4].

Determination of Catalase Activities: One blank tube and one sample tube were obtained for determination of catalase activity. $2.8 \mathrm{ml}$ of $30 \mathrm{mM}$ $\mathrm{H}_{2} \mathrm{O}_{2}$ was put into the blank tube and $0.2 \mathrm{ml}$ of phosphate buffer was added. The mixture was shaken swiftly and spectrophotometrically measured (Ati Unicam UV/VIS-UV2-100,England) twice at $240 \mathrm{~nm}$ with 30 second intervals [5]

Statistical analysis: The data were presented as average \pm standard deviation (SD). The data were compared between the groups for continuous variables and chi-square with Student $\mathrm{T}$ test using an SPSS 16.0 data set (SPSS Inc, Chicago, IL , USA). Student $\mathrm{T}$ test was used for variable without normal distribution. $\mathrm{P}$ - value $<0.05$ was considered meaningful.

Results

Serum reduced glutathione (GSH), catalase (CAT) and superoxide dismutase (SOD) activities and serum melondialdehyde (MDA) levels were determined spectrophotometrically. Superoxide dismutase (SOD), catalase (CAT) and serum reduced glutathione (GSH) activities were found to be lower than the healthy control group. The differences were considered statistically meaningful ( $\mathrm{p}: 0.001)$. When the patient group was evaluated in itself, preoperative superoxide dismutase (SOD) and serum reduced glutathione (GSH) activities were found to be higher than the postoperative values. As for the catalase (CAT) activity, preoperative values were found to be lower than the postoperative values. Serum malondialdehyde (MDA) levels were higher in the patient group. The differences were considered statistically meaningful ( $\mathrm{p}: 0.001)$. When the patient group was evaluated in itself, preoperative serum malondialdehyde (MDA) levels were found to be higher than the postoperative values (Table 1).

\section{Discussion}

Reactive oxygen species (ROS) can be result of dysbalance between the production of free radicals and antioxidant system which plays a role inthe pathogenesis of fatal diseases such as cancer and cardiovascular diseases [6]. Free radicals are implicated that immune system, digestive system, heart, lungs, muscle-related diseases with aging, atherosclerosis, cancer, diabetes, rheumatoid arthritis in many pathological conditions [7].

In these pathological conditions, when catalase, glutathione, glutathione peroxidase, superoxide dismutase prevents, the cell enzyme functions are also fully maintains. Antioxidant enzymatic activity of the cells is sufficient resistance to oncogenic substances increases. Enzymes such as catalase, glutathione, glutathione peroxidase and superoxide dismutase enzymes are protected from necrotic degradation of organism [7].

Table 1: Serum reduced glutathione (GSH), catalase (CAT) and superoxide dismutase (SOD) activities and serum malondialdehyde (MDA) levels in patient (pre- and post-operation) and control groups

\begin{tabular}{|c|c|c|c|c|}
\hline Parameters & $\begin{array}{l}\text { Healthy control group } \\
(\mathrm{N}: 35) \mathrm{X} \pm \mathrm{Sx}\end{array}$ & $\begin{array}{l}\text { Preoperative values of the } \\
\text { patient group } \\
(\mathrm{N}: 35) \mathrm{X} \pm \mathrm{Sx}\end{array}$ & $\begin{array}{l}\text { Postoperative values of the } \\
\text { patient group } \\
(\mathrm{N}: 35) \mathrm{X} \pm \mathrm{Sx}\end{array}$ & $\mathrm{p}$ \\
\hline SOD $(\mathrm{EU} / \mathrm{ml})$ & $81.56^{\mathrm{a}} \pm 2.42$ & $43.25^{*} \pm 6.29$ & $37.94 \pm 6.04$ & 0.001 \\
\hline $\mathrm{CAT}(\mathrm{EU} / \mathrm{ml})$ & $0.0163^{\mathrm{a}} \pm 0.006$ & $0.0006^{*} \pm 0.0006$ & $0.0024^{\mathrm{c}} \pm 0.0036$ & 0.001 \\
\hline $\operatorname{MDA}(\mathrm{nmol} / \mathrm{ml})$ & $0.274^{\mathrm{a}} \pm 0.046$ & $0.866^{*} \pm 0.502$ & $0.960^{c} \pm 0.241$ & 0.001 \\
\hline $\mathrm{GSH}(\mathrm{nmol} / \mathrm{ml})$ & $0.174^{\mathrm{a}} \pm 0.057$ & $0.008^{*} \pm 0.007$ & $0.005^{\mathrm{c}} \pm 0.004$ & 0.001 \\
\hline
\end{tabular}

The values should be read as average \pm standard deviation.

1: The difference between ${ }^{a}$ and $*$ is meaningful. $(\mathrm{p}<0.05)$

2: The difference between ${ }^{\mathrm{a}}$ and $^{\mathrm{c}}$ is meaningful. $(\mathrm{p}<0.05)$

3: The difference between $*$ and ${ }^{\mathrm{c}}$ is meaningful. $(\mathrm{p}<0.05)$ 
Antioxidants inhibit the activities of free radicals and play a preventive role in tumor-related processes. Many synthetic and natural antioxidants have a positive effect on human health and they are also considered to prevent some diseases [8]. For this reason, the functions of antioxidants are important for preventing the formation of free radicals or breaking the chains. It was shown that antioxidants neutralize free radicals and prevent cell damage [9]. There are some contradictory studies in literature regarding antioxidant activities in patients with cancer. SOD activity in esophageal cancer patients have been found lower than those in healthy people [10]. Serum SOD activities were found to be lower in patients with ovarian cancer compared to the healthy control group (Table 1). This finding should be evaluated in wide scale studies.

MDA level in esophageal cancer patients have been found higher than those in healthy people [10]. Meaningfully high serum MDA levels were found in patients with ovarian cancer (Table 1). In literature, glutation activity has been found significantly lower in patients with esophageal squamous cell carcinoma than in controls. In this study, the serum GSH activity was observed to decrease in patients with ovarian cancer. In the literature, catalase enzyme activity is usually reduced in esophageal squamous cell carcinoma [10]. The serum CAT activity was found significantly lower in patients with ovarian cancer than controls $(\mathrm{p}<0.05)$.

Conclusion

Some studies found higher GSH levels in primary and metastatic ovarian malignancies, than found in benign ovarian tumor samples or normal ovarian tissue. Differently from the literature, our study found higher serum reduced glutathione (GSH) levels in the healthy control group compared to the patient group with ovarian neoplasia $[11,12]$.

Financial Support:This research received no specific grant from any funding agency, commercial or not-for-profit sectors

Conflict of Interest: The authors declare no potential conflicts of interest with respect to the research, authorship, and/or publication of this article.

\section{References}

1. Hybertson BM, Gao B, Bose SK, McCord JM. Oxidative stress in health and disease: the therapeutic potential of Nrf2 activation. Molecular aspects of medicine. 2011;32(4-6):234-46.

2. Pirincci N, Kaba M, Gecit I, Gunes M, Yuksel MB, Tanik $\mathrm{S}$, et al. Serum prolidase activity, oxidative stress, and antioxidant enzyme levels in patients with renal cell carcinoma. Toxicology and industrial health. 2013.

3. McCord JM, Fridovich I. Superoxide dismutase. An enzymic function for erythrocuprein (hemocuprein). The Journal of biological chemistry. 1969;244(22):6049-55

4. Beutler E, Duron O, Kelly BM. Improved method for the determination of blood glutathione. The Journal of laboratory and clinical medicine. 1963;61:882-8.

5. Aebi H. Catalase in vitro. Methods in enzymology. 1984;105:121-6.

6. Kopani M, Celec P, Danisovic L, Michalka P, Biro C. Oxidative stress and electron spin resonance. Clinica chimica acta; international journal of clinical chemistry. 2006;364(1-2):61-6.

7. Koca N, Karadeniz F. Serbest radikal oluşum mekanizmalari ve vücuttaki antioksidan savunma sistemleri. Gida Muh.Dergisi, Ankara. 2014;32-37.

8. Bagchi D, Bagchi M, Stohs SJ, Das DK, Ray SD, Kuszynski CA, et al. Free radicals and grape seed proanthocyanidin extract: importance in human health and disease prevention. Toxicology. 2000;148(2-3):187-97.

9. Gökpinar Ş, Kora, T, Akçiçek E, Göksan T, Durmaz Y. Algale antioxidants. Ege Ünivesitesi. Aqua Culture Magazine. 2006;23:85-89.

10. Sehitogullari A, Aslan M, Sayir F, Kahraman A, Demir H. Serum paraoxonase-1 enzyme activities and oxidative stress levels in patients with esophageal squamous cell carcinoma. Redox report : communications in free radical research. 2014;19(5):199-205.

11. Sprem M, Babic D, Abramic M, Vrhovec I, Skrk J, Milicic D, et al. Glutathione and glutathione Stransferases as early markers for ovarian carcinomas: case series. Croatian medical journal. 2001;42(6):624-9.

12. Abou Ghalia AH, Fouad IM. Glutathione and its metabolizing enzymes in patients with different benign and malignant diseases. Clinical biochemistry. 2000;33(8):657-62. 